\title{
Visualization of Morphology by Rib Destruction When Exposed to A Stab-Cut Object
}

\author{
M.A. Kislov'1, K.N. Krupin² \\ I.M. Sechenov First Moscow State Medical University (Sechenov University) \\ ${ }^{1}$ ORCID: 0000-0002-9303-7640, kislov@1msmu.ru \\ 2 ORCID: 0000-0001-6999-8524, krupin@1msmu.ru
}

\begin{abstract}
This paper discuss the establishing and visualization of the morphological signs of stab injury to the rib with field experiments and mathematical modeling. We reveal the regularities of the load distribution in the bone tissue in this type of injury. With the help of objective research methods, the localization of the action zone of the knife blade tip and the transition of end cutting to longitudinal cutting with subsequent visualization is explained. The application of the method of finite element analysis of stab injury of bone tissue is proposed.
\end{abstract}

Keywords: finite element analysis, stab injury, visualization, rib.

\section{Introduction}

The increased modern requirements for the assessment of the presented material objects in the work of forensic medical experts is a subject of this research. For this purpose, many different physical and chemical methods of instrumental research are used. In this case, the method of non-strict analogy is usually used, where the direct feature under study isn't related to a similar one. The research using this method often provides the results of a probabilistic nature. A non-strict analogy is the case of the dependence between similar and transferable signs is thought to be necessary only with a greater or lesser degree of probability. In this case, if we find a sign of similarity in another object, we can only conclude in a logically weakened form that the transferred attribute belongs to the latter [1].

Nevertheless, forensic medical examination doesn't allow using the methods that give only probabilistic results. Therefore, in modern forensic medicine, statistical analysis data are used to determine diagnostic signs characteristic of specific types of traumatic effects [2-4].

Currently, modern computer technologies have become widespread in biomechanics and forensic medicine. The area takes advantage of three-dimensional software modeling of objects, mathematical modeling, etc., which corresponds to the general direction of high-tech research methods in medicine. Methods and software products that allow visualizing physical processes are becoming increasingly widespread. To solve expert questions, the data from physics and mathematics are used, concepts and laws of mechanics of a deformed solid, the theory of cutting materials, etc. are used.

Thus, the method of finite element analysis (FEA), that is conventionally used for solving problems of deformable solid mechanics, electro-and magnetostatics, gas dynamics, as well as other fields of physics, is also used to assess the energy distribution in solid tissues. Finite element analysis is based on the use of the mathematical finite element method.

The finite element method (FEM) is a numerical method for solving partial differential equations, as well as integral equations arising in solving problems of applied physics, which has been used since the 1950s. At this time, the method was not widely used due to the low level of computer technology. With the development of technical capabilities, the possibilities of using the method have expanded. Currently, the method is widely used to solve problems 
of deformable solid mechanics in the science of "resistance of materials", heat transfer, hydro-gas dynamics and electrodynamics $[6,7]$.

In modern conditions, it has become impossible to use tracological studies on living tissues, which leads to doubts about the reliability of the experimental results and the value of the study as a whole. A promising method of research under these conditions is the method of mathematical modeling of the destruction of biological tissues, considering the mechanical properties of biological tissues and boundary conditions [8-12, 15]. The purpose of this work was to analyze the possibility of using the finite element method in modern conditions to solve problems in the study of stab injuries of ribs.

\section{Methods of research}

The rib is a helically curved irregular elliptical cylinder consisting of spongy bone tissue with a thin layer of compact bone tissue on the outer surface (Fig. 1).

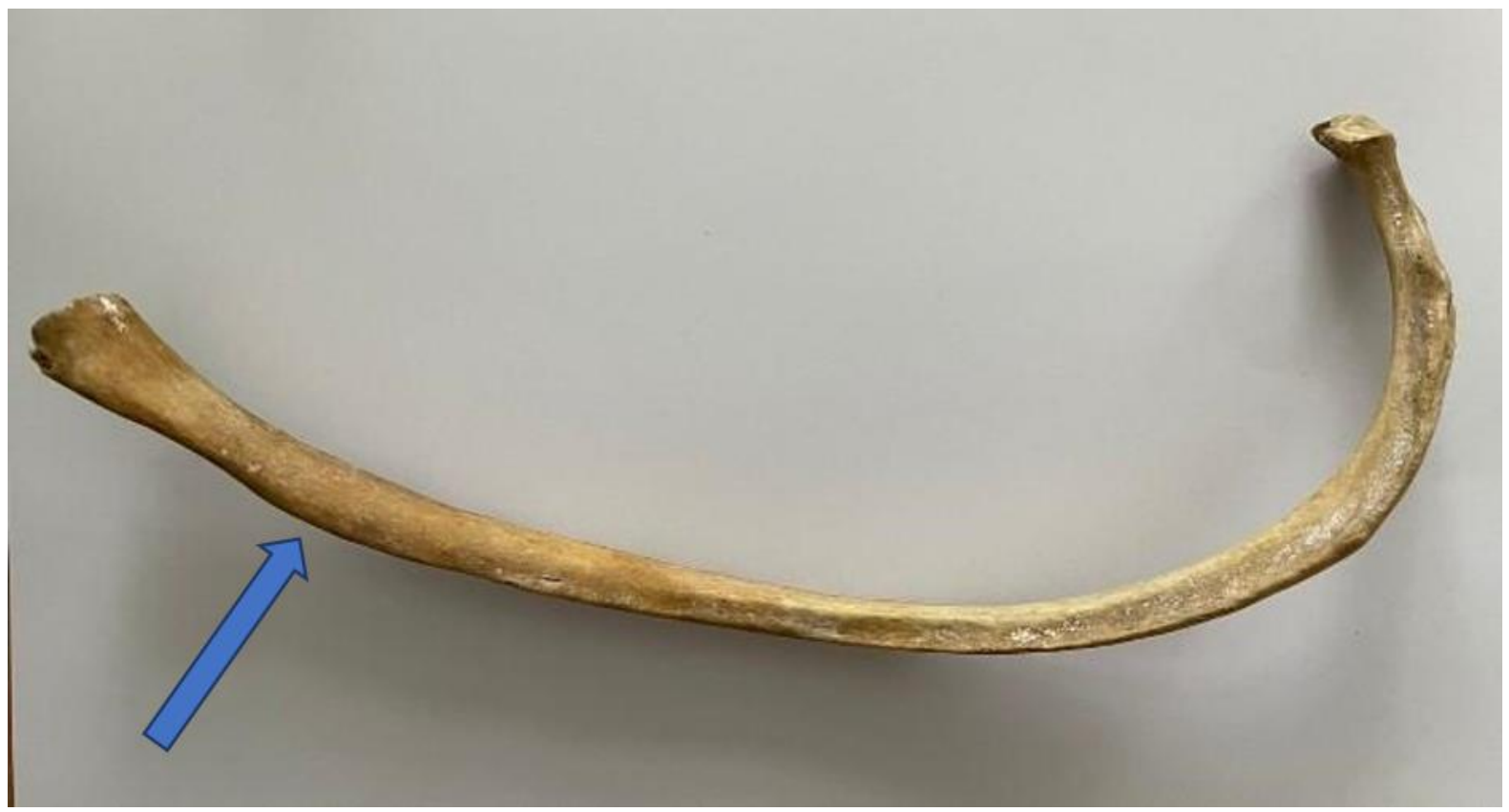

Fig. 1. Photo of a native cleaned edge. The arrow indicates the front flat part of the rib.

The rib preparations were carried out in the following way: bones were degreased in an aqueous solution of sodium laurate, then dried for 2-3 days.

In some cases, graphite powder was contrasted, which was applied to the edges of the damage to eliminate glare during photography and microscopy.

The samples were also degreased and the damage surface was shaded.

To reduce the reflection of light during photographing and microscopy of stab injuries, as well as to increase the contrast of individual elements of the bone profile, the surface was shaded. The edges of the bone injuries were treated with a $5 \%$ solution of iodine and a solution of brilliant green (2\%), then fine soot was sprayed on the surface of the damage.

Next, the bone macro-preparations were examined using a binocular magnifier and an MBS-10 stereomicroscope.

In full-scale experimental studies on biomanequins, morphological signs of damage to a human rib were studied under the impact of a piercing-cutting object under conditions of translational movement of a hand with a knife at a speed of up to $10 \mathrm{~m} / \mathrm{s}$ along the flat part of the anterior third of the fixed rib with the orientation of the blade axis of the knife blade along the axis of the bone.

In experimental studies, the data of the knife blade were used: the depth of immersion of the blade was $54 \mathrm{~mm}$; the width of the blade at this level of immersion was $17-17.5 \mathrm{~mm}$; the 
thickness of the blade in the middle part of the butt was $1.2 \mathrm{~mm}$; the knife had a pronounced tip zone (Fig. 2) [13, 16].

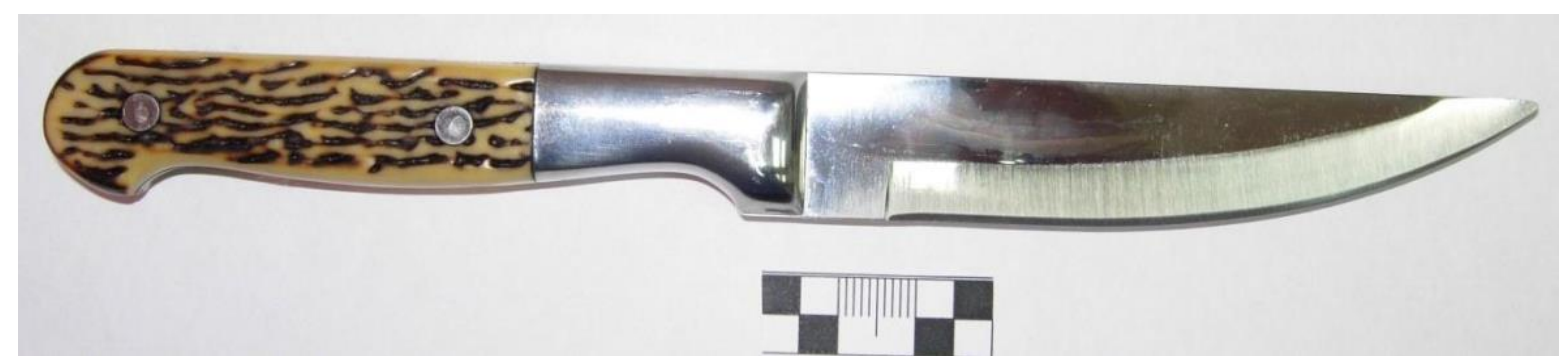

Fig. 2. Photo of the knife used in field experiments.

We used FEM to visualize and find out the possibilities of mathematical modeling of the process of forming a rib injury that occurs at the injection point.

For mathematical modeling, we created the three-dimensional graphic models of the blade of a piercing-cutting trace-forming object and a trace-receiving material-bone in the ANSYS EXPLICIT DYNAMICS 2020 R2[17] software package.

ANSYS is one of the popular software environments for finite element analysis, for solving linear and nonlinear problems of deformable solid mechanics, developed by the American company Ansys inc. and used for the analysis of the destruction of solids, including in forensic medicine.

The biophysical parameters of the rib were set as averaged, obtained during the study of various sections of the rib. The blade of the knife is modeled according to the data of a fullscale experiment made of steel with standard parameters [18]. A model of the rib segment with the physical parameters of the spongy bone was constructed: density $200 \mathrm{~kg} / \mathrm{m}^{3}$, Young's modulus $17000 \mathrm{MPa}$, yield strength $110 \mathrm{MPa}$ [19]. The finite element grid is generated in an automated mode by Solid type finite elements, which are used to simulate a volumetric stress-strain state. The restriction is set for the movement of the bone and the knife blade perpendicular to the plane of symmetry of the edge. The impact action of the knife blade in the model is modeled perpendicular to the edge axis with a force of $5000 \mathrm{~N}$ and a speed of $10000 \mathrm{~mm} / \mathrm{s}$, while its movements are limited in all directions except vertical, with the application of forces on the upper surface of the blade model. The rib was regarded by us as a beam with sealing of the ends (cantilever attachment) (Fig. 3).

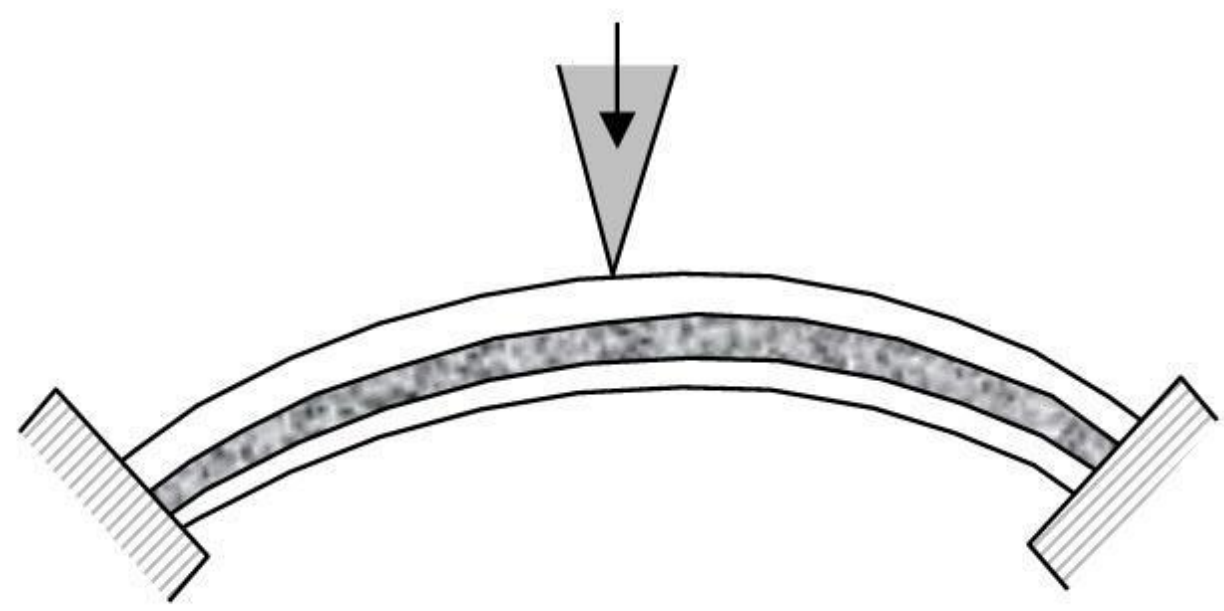

Fig. 3. The scheme of the support of the rib as a beam with the sealing of the ends - a cantilever attachment. 


\section{Results and discussion}

In the field experiments conducted along the axis of the rib, through-through injuries repeated the shape of a one-sided sharp blade and displayed its cross-sectional shape.

A bone tissue defect with edges formed by crushed bone tissue was found in the injection zone. The shape of the defect at the injection point approached an isosceles triangle and corresponded to the size of the zone of action of the experimental knife tip (Fig. 4).

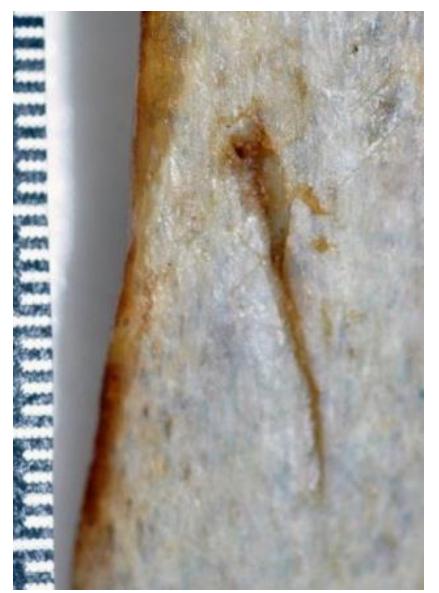

Fig. 4. Type of stab injury to the rib in a full-scale experiment (view from the side of the external bone plate).

Smooth edges of bone tissue damage were recorded in the continuation of the crumpling zone. The smooth, linear separation zone, the parallelism of the opposite edges to each other in all planes testified to the effect of the cutting edge of the blade on bone.

Three zones are distinguished in the damage profilogram (Fig. 5):

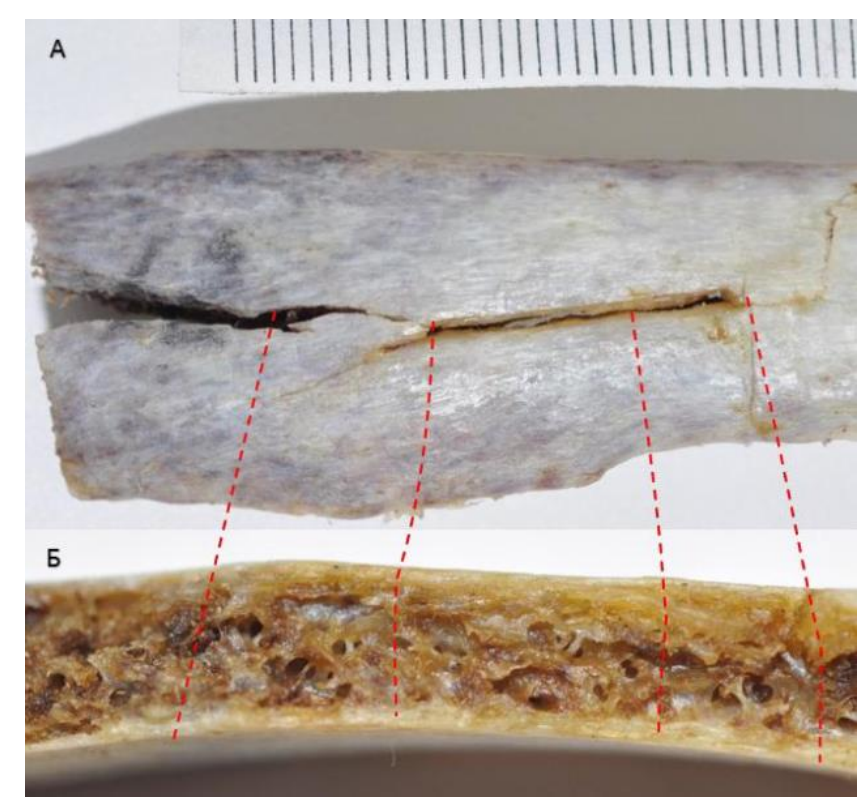

Fig. 5. Morphology of a stab injury to a rib: a-view from the side of the external bone plate, bprofile of the injury in the bone. The lines mark the areas where the edges and walls of the damage correspond.

1. In the zone of action of the knife tip zone, a longitudinal stratification of bone tissue, a crumpling (flattening in the transverse direction) of the cells of the spongy substance of the bone is recorded. There is a transfer of fragments of the external bone plate deep into the damage. According to the action of the edge of the butt of the knife blade, the area of grinding (erasure, flattening) of the compact and spongy substance of the bone tissue is clearly 
recorded with the naked eye. This correspondence is explained by a single mechanism of damage formation - end cutting; a profile study of the walls of the wound canal of the injury allows you to clearly determine the point of injection - the zone of action of the tip of the knife blade. The nature of the deformation of the outer bone plate and the cells of the spongy substance allows us to assess the direction of the impact of the blade tip and the metric characteristics of the blade tip. The transition from the first section to the second was recorded in the form of an arc-shaped bend of the edge and the wall of the damage (Fig. 6);

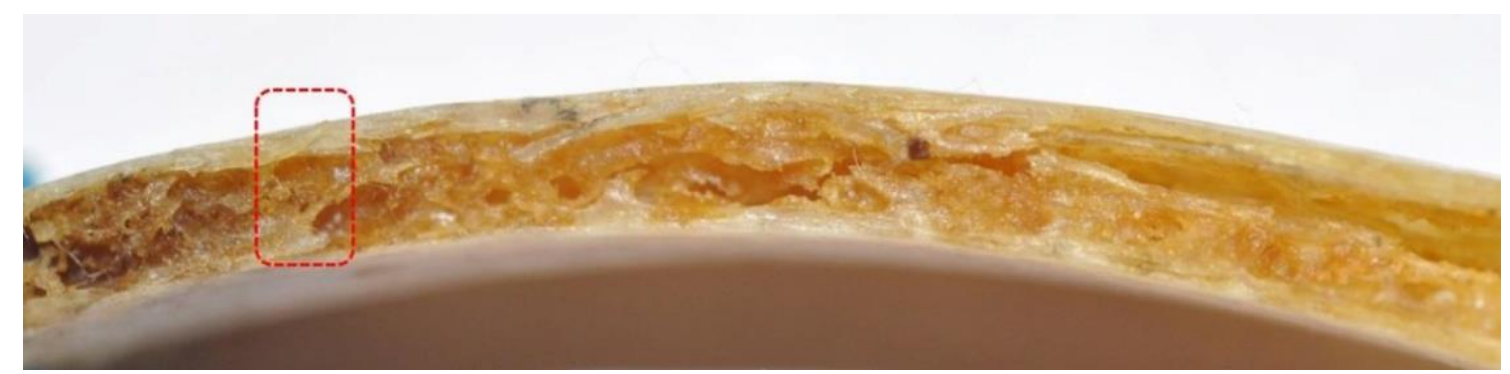

Fig. 6. Visualization of the injection point of a stab injury to the rib

2. In the area of the blade action (cutting itself), there is no macroscopically deformed cells of the spongy bone tissue and an even plane of separation is determined;

3. When examining the area of the zone of action of the blade tip of the knife, the separation plane is clearly defined, which was presented in the form of slightly protruding and sinking smooth wavy sections. The most protruding areas of the bone had a pronounced shine - this indicated that the surface was sanded from the action of the blade sharpening fields (Fig. 7). This feature corresponds to the data of the theory of cutting materials: when cutting longitudinally, the blade forms a crack in front of it, then the sharpening fields acting on the walls provide immersion of the blade wedge.

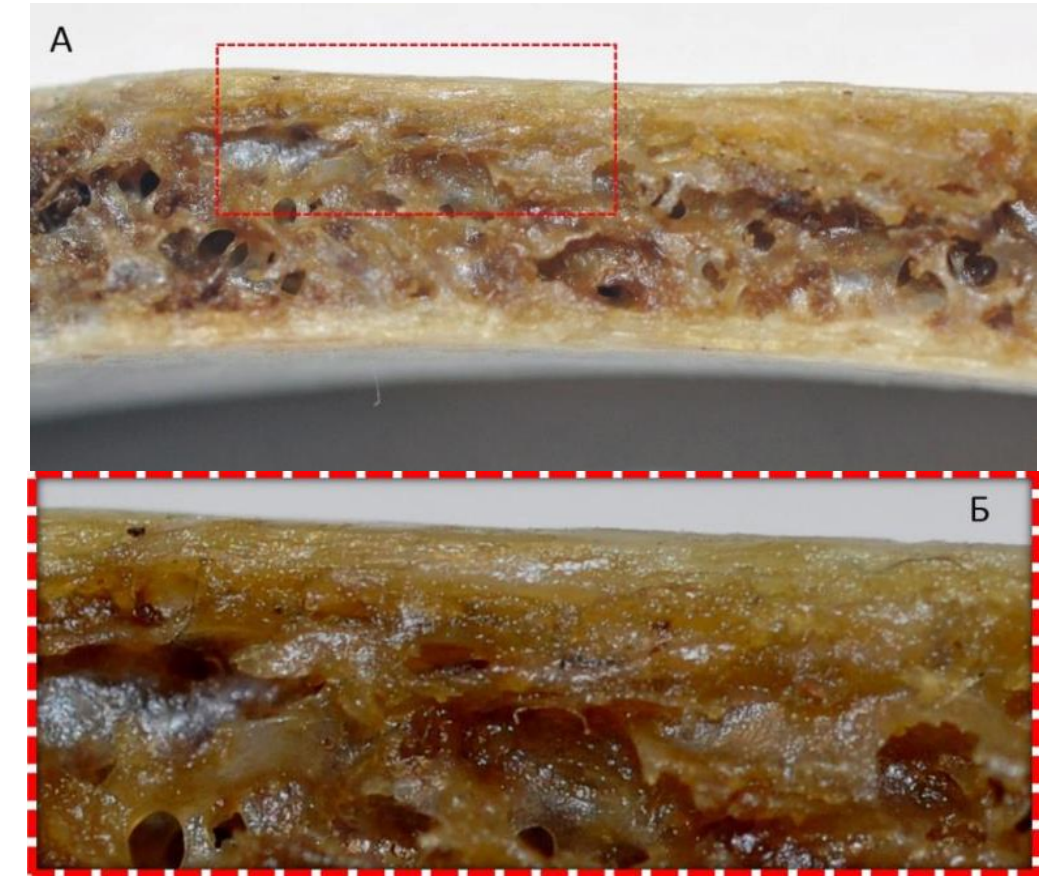

Fig. 7. The cutting area on the wall of the stab injury of the rib: small fragments of bone tissue are visualized ( $a$ - general plan of the wall of the stab injury, b- micrograph of the zone of the leading crack).

As a result of mathematical modeling by the method of finite element analysis, the following results are obtained: 
1. When exposed to the blade of a knife, a critical load of bone tissue occurs with its destruction and the formation of a through damage. Figure 8 shows the last stage of modeling the through penetration of the knife blade along the rib axis with the distribution of equivalent stresses along the Mises in various parts of the bone wound - the maximum equivalent stresses occur in the zone of action of the knife tip at the border with the spine part in the amount of 223.3 MPa. displacement and deformation of finite elements in the outer surface along the axis of action of the blade of the knife model.

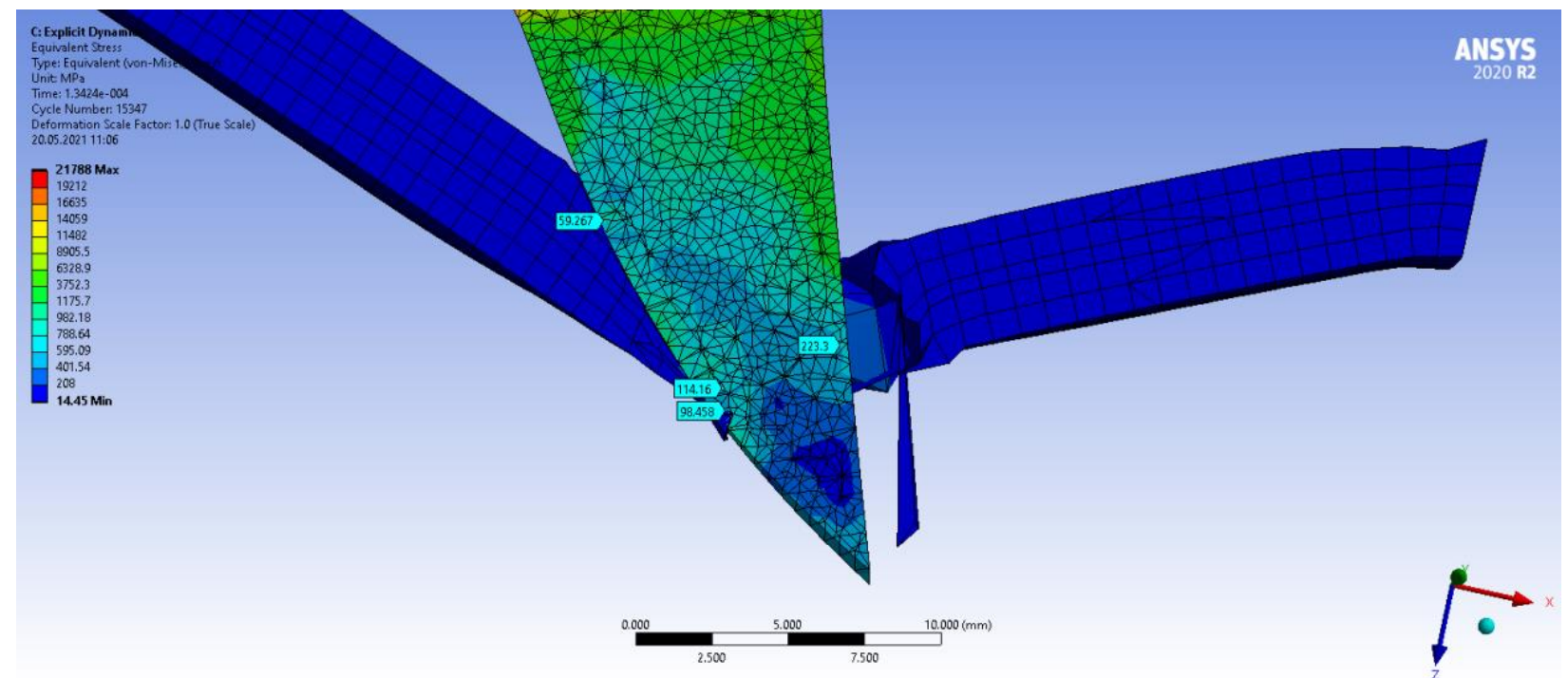

Fig. 8 Mathematical model of the formation of rib damage under the action of a piercingcutting object. Equivalent Mises stresses.

2. When rib is damaged by the blade of a knife blade, bone fragments are displaced in the direction and in the zone of action of the knife blade tip zone with the maximum concentration of equivalent stresses at the edge of the edge zone (114.16 MPa), which indicates a change in the end type of cutting to the longitudinal one, which is shown in Fig. 9.

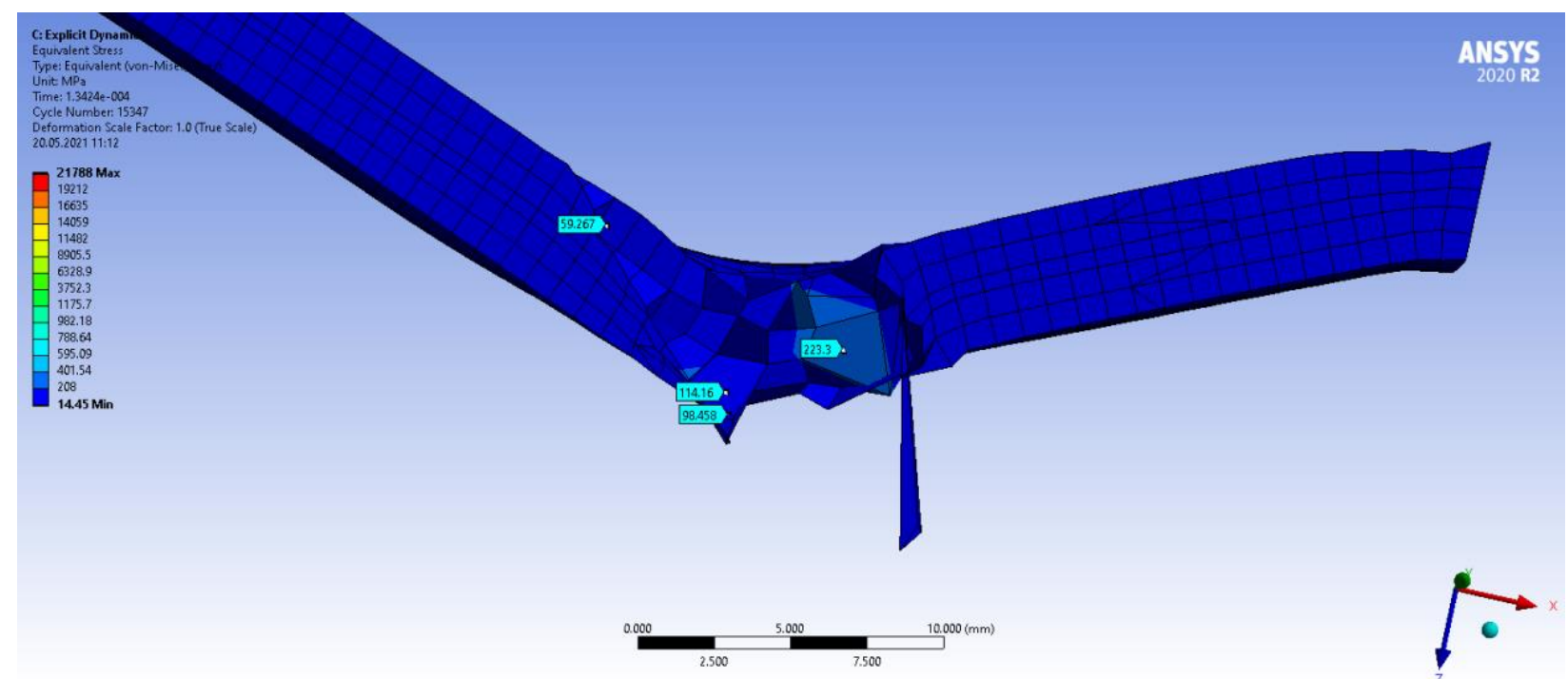

Fig. 9 Mathematical model of rib formation of damage under the action of a piercing-cutting object. Equivalent Mises stresses. The arrow indicates the place of concentration of equivalent stresses during cutting.

3. When analyzing shear stresses in the area of a bone wound, it was found that the maximum concentration of equivalent stresses of bone tissue at the boundary of the action of the tip zone is formed mainly due to shear deformation and is $36.378 \mathrm{MPa}$ (Fig. 10). 


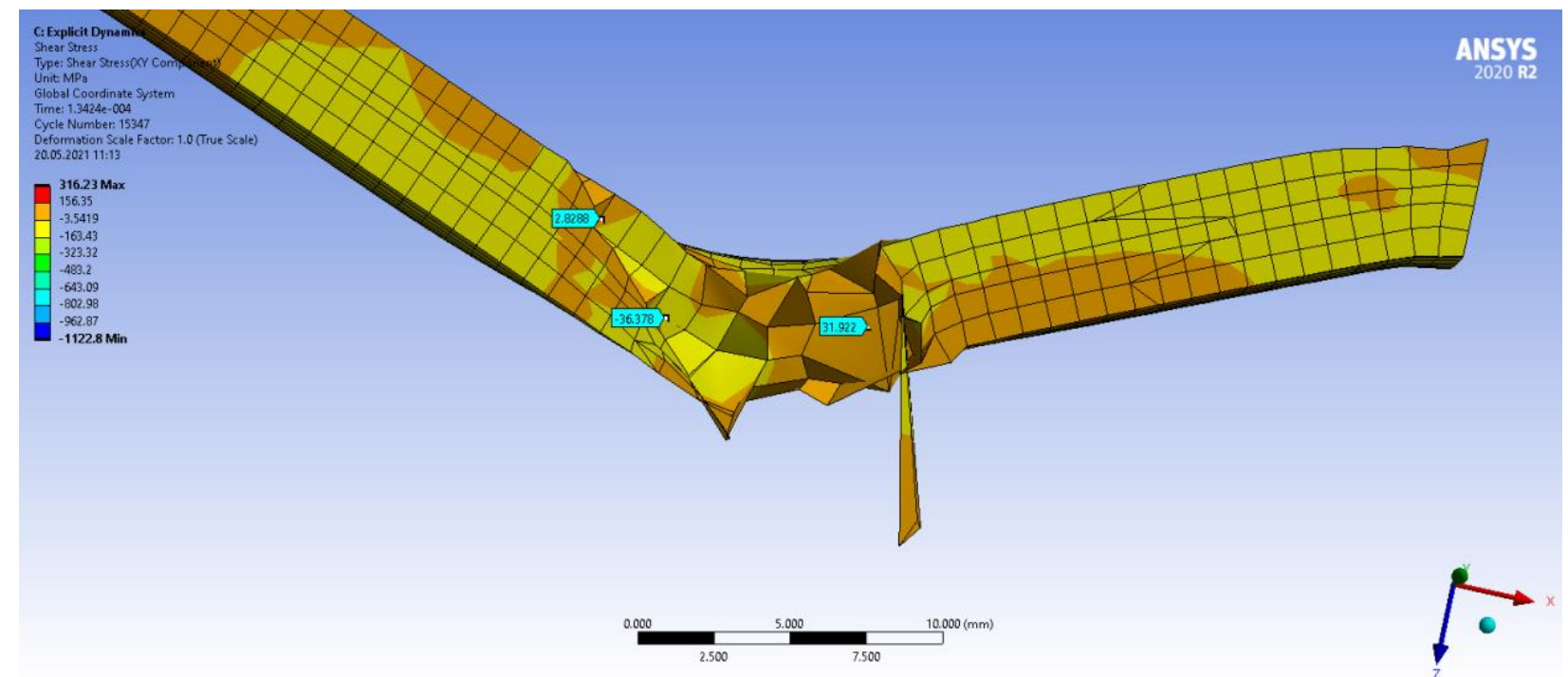

Fig. 10 Mathematical model of rib formation damage under the action of a piercing-cutting object. Shear stresses. The arrow indicates the location of the shear stress concentration.

- When comparing the results of field experiments and finite element analysis of the destruction of the rib from the piercing-cutting action of the knife blade, it was found full correspondence of the location of the bone wound zones and morphological features in the damage profilograms (Fig. 11):

- The zone of action of the knife tip (the injection point) is detected. It is manifested by the area of compression, deformation and displacement of the elements of the outer plates into the damage with the maximum concentration of equivalent stresses;

- In the area of action of the knife blade, there is a crumpling and displacement of the finite elements transversely to the axis of action of the knife blade with a minimum concentration of equivalent stresses;

- At the boundary of these two zones, a surge of equivalent stresses due to shear deformation is determined, indicating a change in the end type of cutting to the longitudinal and the end of the zone of the blade edge of the knife.
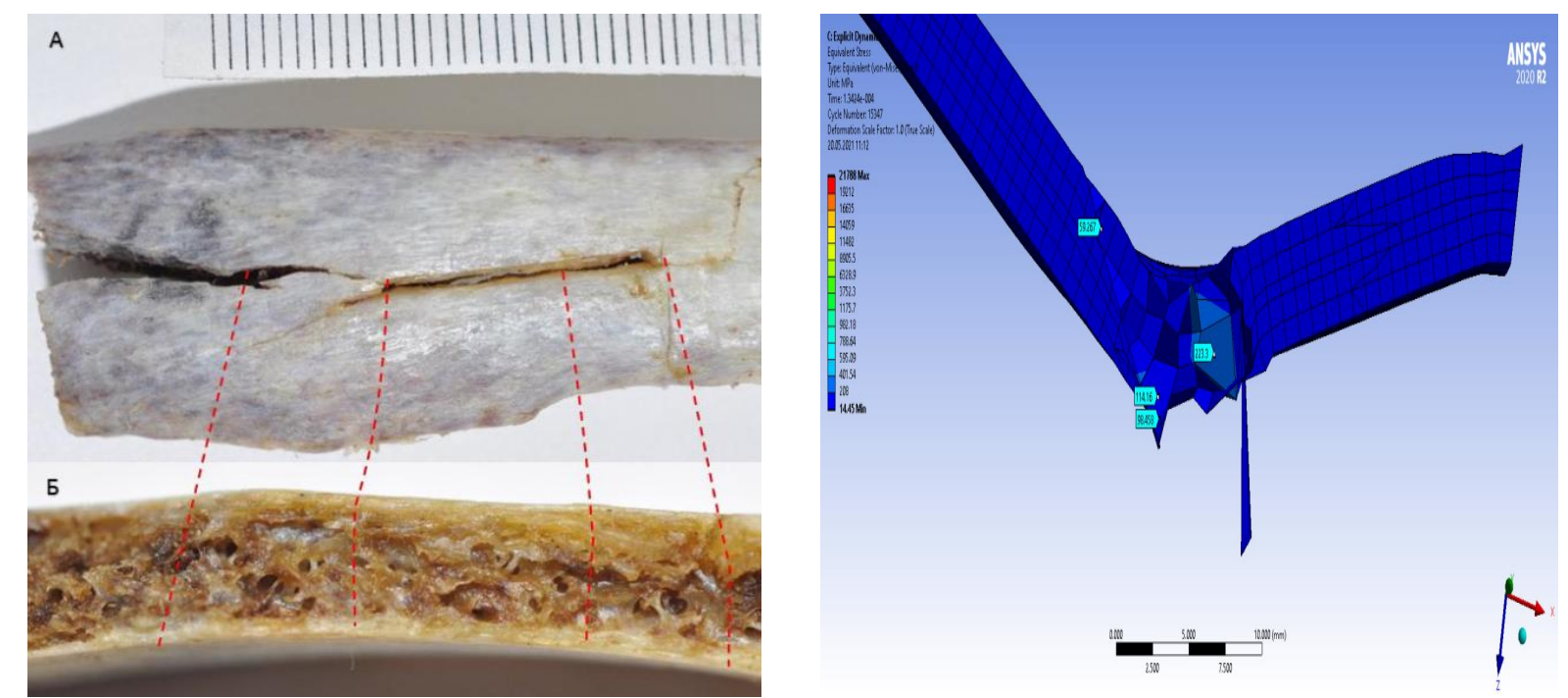

Fig. 11. Comparison of the profilogram of experimental full-scale damage (left) and the profile of the results of finite element modeling (right). The similarity of the location and morphology of the bone damage zones is noted. 
Thus, the mathematica model traces all the main morphological signs of the native experimental stab injury of the rib. As a result of a comparative study, we were able to establish the possibility of using the method of finite element analysis for the study of stabcut injuries and justified the morphological basis of the transition point of end-tolongitudinal cutting at the border of the action zone of the knife edge.

\section{Conclusion}

Thus, the use of mathematical modeling of FEM allows visualizing and predicting the stresses that arise in the trace-receiving material when exposed to the pronounced zone of the blade tip of a piercing-cutting object. The results of computer simulation are confirmed by the results of original field experiments [13].

It should be noted that at the moment, due to the weak introduction of FEM into expert practice, the authors of the article cannot assess how reliably this method will allow predicting the process of destruction of biological objects under various types of mechanical impact, as well as to assess the scope of practical use and demand for mathematical modeling of FEM in forensic medicine. In forensic medicine, there are no methods for mathematical analysis and modeling of the process of destruction of biological objects as a result of the influence of mechanical factors, so we consider the use of FEM to be the most promising at the moment.

Data from foreign sources on the use of FEM in modeling the fall, the behavior of implants in bone tissue, and skin destruction suggest a high efficiency of the method [11, 12, 14].

The use of FEM in forensic medicine in the future allows reliable prediction of the process of destruction of biological objects under various types of mechanical impact with further visualization, and in the future, it is possible to solve the inverse problem - to speak about the tracological properties of the traumatic tool based on the morphological picture of destruction.

\section{References}

1. Kirillov V.I., Starchenko A.A. Logika: Uchebnik dlya yuridicheskih vuzov. - Izd. 5-e, pererab. i dop. - M.: YUrist", 1999. - 256 p. [in Russian]

2. Leonov S.V., Krupin K.N. Sudebno-medicinskaya ocenka morfologii koloto-rezanyh ran, sformirovannyh klinkami nozhej s razlichnymi defektami ostriya // Medicinskaya ekspertiza i pravo. 2012. № 1. P. 37-39.

3. Krupin K.N., Vlasyuk I.V. Otobrazhenieekspluatacionnyhdefektovostriyakolyushcherezhushchegoorudiya v povrezhdeniyahkozhnogopokrova// Medicinskayaekspertiza i pravo. 2013. № 2. P. 28-31.[in Russian]

4. Kislov M.A., Leonov S.V. Ispol'zovanie metoda konechnyh elementov dlya prognozirovaniya razrusheniya koloto-rezanyh povrezhdenij ploskih kostej// Medicinskaya ekspertiza i pravo. 2016. № 3. P. 22-24. [in Russian]

5. Leonov S.V., Kislov M.A. Morfologicheskie osobennosti koloto-rezanyh povrezhdenij reber pri vozdejstvii kolyushche-rezhushchim predmetom vdol' kompakty// Medicinskaya ekspertiza i pravo. 2015. № 3. P. 21-23. [in Russian]

6. Zenkevich O. Metod konechnyh elementov v tekhnike. M: Mir 1975; 318. [in Russian]

7. Leonov S.V., Pinchuk P.V., Krupin K.N., Panfilov D.A. The mathematical modeling of the injurious impact on the tibial bone for the evaluation of the conditions leading to its fracture // Forensic Medical Expertise. 2017. Volume. 60. № 2. P. 11-13. https://doi.org/10.17116/sudmed201760211-13

8. M. Milanowicz, K. Kedzior Active numerical model of human body for reconstruction of falls from height // Forensic Science International (2016). http://dx.doi.org/10.1016/j.forsciint.2016.10.009 
9. Panfilov D.A., Romanchikov V.V., Krupin K.N. Solving cross-disciplinary problems by mathematical modelling // IOP Conference Series: Materials Science and Engineering. 2018. P. 022080. https://doi.org/10.1088/1757-899X/327/2/022080

10. Pinchuk P.V., Krupin K.N., Petrov V.V., Leonov S.V. Specific fractures of the diaphysis of the femur formed by a traumatic multicomponent bullet shot charge from a smoothbore carbine "saiga 12k" at a distance in focus, visualization and theoretical study of the fragment formation mechanism about them // Scientific Visualization. 2018. Volume. 10. № 2. P. 15-28https://doi.org/10.26583/sv.10.2.02

11. Terzini, M., Aldieri, A., Nurisso, S., De Nisco, G., Bignardi, C. Finite Element Modeling Application in Forensic Practice: A Periprosthetic Femoral Fracture Case Study // Frontiers in Bioengineering and Biotechnology Volume 8, 23 June 2020, 619 DOI: 10.3389/fbioe.2020.00619

12. H. Muggenthaler, M. Hubig, A. Meierhofer. G. Mall Slip and tilt: modeling falls over railings // International Journal of Legal Medicine volume 135, pages245-251 (2021) https://doi.org/10.1007/s00414-020-02432-8

13. Kislov M.A. Morfologiya I mekhanika razrusheniya kostnoj tkani pod dejstviem kolyushche-rezhushchih orudij: dissertaciya ... doktora Medicinskih nauk: 14.03.05 // Kislov Maksim Aleksandrovich; - Moskva, 2016.- 241 p. [in Russian]

14. Leonov S.V., Vlasiuk I.V., Krupin K.N. Simulation of the mechanisms of formation of stab and slash wounds by the finite element method // Forensic Medical Expertise. 2013. volume. 56. № 6. P. 14-16.

15. Krupin K.N. Current application possibility of mathematical modeling using the finite element method in forensic medicine//Vestnik medicinskogo instituta "REAVIZ": reabilitaciya, vrach i zdorov'e. 2017. № 6 (30). P. 127-132.

16. Leonov S.V., Kislov M.A. The morphology of the profile flat bones with stab injuries / Medicinskaya ekspertiza i pravo. 2015. № 4. P. 10-11.

17. ANSYS ${ }^{\circledR}$ EXPLICIT DYNAMICS 2020, Release 2 https://www.ansys.com/

18. Structural steel fatigue data at zero mean stress, ASME BPV Code, Section 8, Div 2, Table 5-110.1, (1998).

19. Martin, R. B. Skeletal Tissue Mechanics / R. B. Martin, D. B. Burr, N. A. Sharkey. New-York : Springer, 1998. - P. 347. 